\title{
STUDI ANALISIS PERENCANAAN PENINGKATAN RUAS JALAN MANTINGAN-NGABUL / JALAN SULTAN HADLIRIN
}

\author{
Ariyanto, Alamsyah Noor Ahmad \\ Prodi Teknik Sipil, Fakultas Sains dan Teknologi,Universitas Islam Nahdlatul Ulama Jepara \\ ariyanto@unisnu.ac.id, Alamsyahart97@gmail.com
}

\begin{abstract}
The development of roads in the City of Jepara continues to increase and the width of the road is insufficient to accommodate the traffic capacity causing flow obstruction and the road has an existing structural decline, causing the sections to be bumpy and potholes. It is necessary to do an analysis study on the improvement of the Mantingan-Ngabul road / Sultan Hadlirin road, Jepara Regency in order to solve this problem. From the analysis results obtained as follows: The ideal road widening for this road is at least $6 \mathrm{~m}$. The analysis for calculating the pavement thickness index (ITP) for a 20 year plan age is Laston MS 744 with a thickness of $10 \mathrm{~cm}$, Broken Stone Class A (CBR100\%) with a thickness of $20 \mathrm{~cm}$, and Sirtu Class A (CBR70\%) with a thickness of $25.4 \mathrm{~cm}$. The results of the geometric analysis of the highway where 5 S-S bends are obtained, with details of bend 1 requiring side freedom of $2.75 \mathrm{~m}$, bend 2 of $3.17 \mathrm{~m}$, bend 4 of $2.80 \mathrm{~m}$, bend 5 of $3.11 \mathrm{~m}$ and bend widening is not required. For bend 3 requires side freedom of 13,725 $\mathrm{m}$ and a bend widening of $1 \mathrm{~m}$ is required from the original width of $7 \mathrm{~m}$. According to the analysis, the road capacity of the Mantingan - Ngabul / Sultan Hadlirin road, Jepara Regency, obtained an average traffic growth rate of $2.6 \%$ and the number of LHR per year as follows: In 20204440 the number of vehicles / day. In 2025, there are 5048 vehicles / day. In 2030, there are 5739 the number of vehicles / day. In 2035, it is 6525 the number of vehicles / day. In 2040, 7419 the number of vehicles / day.
\end{abstract}

Keywords: planning, improvement, road, geometry

\begin{abstract}
Abstrak
Perkembangan jalan di Kota Jepara terus meningkat dan lebar jalan yang kurang memadahi untuk menampung kapasitas lalu lintas menyebabkan penghambatan arus dan ruas jalan mengalami existing penurunan srtuktur, sehingga menyebabkan ruas tersebut bergelombang dan berlubang. Hal ini perlu dilakukan studi analisis peningkatan ruas jalan Mantingan-Ngabul / jalan Sultan Hadlirin Kabupaten Jepara agar menyelesaikan permasalahan tersebut. Dari hasil analisis didapat sebagai berikut Pelebaran jalan ideal untuk jalan ini adalah minimal $6 \mathrm{~m}$. Analisis perhitungan Indeks Tebal Perkerasan (ITP) untuk umur rencana 20 tahun adalah Laston MS 744 dengan tebal $10 \mathrm{~cm}$, Batu Pecah Kelas A (CBR100\%) dengan tebal 20 cm, dan Sirtu Kelas A (CBR70\%) dengan tebal $25.4 \mathrm{~cm}$. Hasil analisis geometrik jalan raya di dapat 5 tikungan S-S dengan rincian tikungan 1 membutuhkan kebebasan samping $2.75 \mathrm{~m}$, tikungan 2 sebesar $3.17 \mathrm{~m}$, tikungan 4 sebesar $2.80 \mathrm{~m}$, tikungan 5 sebesar $3.11 \mathrm{~m}$ dan tidak diperlukan pelebaran tikungan. Untuk tikungan 3 membutuhkan kebebasan samping $13.725 \mathrm{~m}$ dan diperlukan pelebaran tikungan sebesar $1 \mathrm{~m}$ dari lebar asli sebesar $7 \mathrm{~m}$. Sesuai analisis, kapasitas ruas jalan Mantingan - Ngabul / jalan Sultan Hadlirin Kabupaten Jepara di dapat angka pertumbuhan lalu lintas rata-rata sebesar $2.6 \%$.
\end{abstract}

Kata kunci: perencanaan, peningkatan, jalan, geometri

\section{PENDAHULUAN}

Angka perekonomian di Kota Jepara yang meningkat, mengakibatkan aktivitas lalu lintas semakin padat. Maka dari itu, perlu adanya sarana prasarana yang dapat menunjang kegiatan masyarakat, salah satunya yaitu jalan rayayang termasuk bangunan pelengkap untuk kelancaran lalu lintas. Penelitian kali ini difokuskan pada ruasjalan Sultan Hadlirin Kabupaten Jepara, yang mana jalan ini merupakan akses arus lalu lintas yang banyak digunakan masyarakat sekitar.Jalan ini sering dilalui truk-truk 
pengangkut muatan barang berkapasitas besar serta banyak mobil penumpang

Akibat meningkatnya pertumbuhan lalu lintas dan kurangnya kapasitas jalan, arus ruas jalan tersebut mengalami penghambatan dan existing yang berupa perkerasan lentur mengalami penurunan srtuktur dengan kondisi jalan bergelombang yang dapat menyebabkan kecelakaan. Penelitian ini dilakukan untuk merencanakan peningkatan pelebaran ruas jalan yang efisien untuk jalan Mantingan Ngabul / jalan Sultan Hadlirin Kabupaten Jeparadan menentukan tebal perkerasan yang diperlukan untuk umur 20 tahun dengan menggunakan metode perkerasan lentur.

\section{TINJAUAN PUSTAKA}

\section{Klasifikasi dan fungsi jalan}

Klasifikasi jalan berdasarkan (Direktorat Jenderal Bina Marga 1997b) adalah

a. Klasifikasi menurut Fungsi Jalan :

Jalan Arteri : jalan yang melayani angkutan utama dengan ciri-ciri perjalanan jarak jauh, kecepatan rata-rata tinggi, dan jumlah jalan masuk dibatasi secara efisien.

Jalan Kolektor : jalan yang melayani angkutan pengumpul, memiliki jarak perjalanan sedang, kecepatan rata-rata sedang dan jumlah jalan masuk dibatasi.

Jalan Lokal yaitu : yang melayani angkutan setempat dengan ciri-ciri perjalanan jarak dekat, kecepatan rata-rata rendah, dan jumlah jalan masuk tidak dibatasi.

b. Klasifikasi menurut kelas jalan

Klasifkasi menurut kelas jalan dengan kemampuan jalan untuk menerima beban lalu lintas, dinyatakan dalam muatan sumbu terberat (MST) dalam satuan ton.

c. Klasifkasi menurut medan jalan

Medan sebuah jalan dapat diklasifikasikan sesuai keadaan dilapangan. Adapun Klasifikasi jalan berdasarkan medan jalan adalah:

Tabel 1. Klasifikasi Menurut Medan Jalan

\begin{tabular}{|c|c|c|c|}
\hline No & Jenis Medan & Notasi & $\begin{array}{c}\text { Kemiringan } \\
\text { Medan (\%) }\end{array}$ \\
\hline 1 & Datar & D & $<3$ \\
\hline 2 & Perbukitan & B & $3-25$ \\
\hline 3 & Pegunungan & G & $>25$ \\
\hline
\end{tabular}

(Sumber :Bina Marga Pt T-01-2002-B)

\section{Perhitungan analisis kapasitas jalan}

Kapasitas adalah Arus LaluLintasmaksimum (smp/jam) yang dapat dipertahankan sepanjang potongan jalan dalam kondisi tertentu. Analisis ini sangat berpengaruh dalam Tahapan Penentuan Lebar Ruas Jalan.

Tingkatan analisis yang digunakan adalah analisis operasional dan perencanaan, yaitu penentuan kinerja segmen jalan akibat kebutuhan lalu-lintas. Beberapa Parameter dalam penentuan lebar jalan berdasar pada analisis kapasitas jalan adalah sebagai berikut (Direktorat Jenderal Bina Marga 1997a) :

a. Kapasitas Dasar

Kapasitas dasar adalah kapasitas suatu segmen jalan untuk kondisi yang ditentukan sebelumnya (geometrik, pola arus lalu-lintas, dan faktor lengkungan). Pengaruh tipe alinyemen pada kapasitas juga membawa perbedaan bagi kapasitas dasar tersebut.

b. Faktor Penyesuaian Kapasitas Lebar Jalur Lalu -Lintas

Lebar jalur efektif adalah lebar rata-rata yang tersedia untuk pergerakan lalu-lintas setelah pengurangan perkerasan tepi jalan

c. Faktor Penyesuaian Kapasitas Akibat Pemisah Arah

Pemisah arah adalah pembagian arah arus pada jalan dua arah yang dinyatakan sebagai prosentase dari arah arus total.

d. Faktor Penyesuaian Kapasitas Akibat Hambatan Samping

Hambatan samping adalah pengaruh kegiatan samping ruas jalan terhadap kinerja lalu-lintas, misalnya pejalan kaki, perhentian kendaraan umum, kendaraan masuk dan lain lain.

e. Penentuan Kapasitas Pada Kondisi Lapangan

Kapasitas adalah arus maksimum yang dapat dipertahankan persatuan jam yang melewati suatu titik dijalan. Menentukan kapasitas pada kondisi lapangan dapat dipergunakan rumus :

$$
\mathrm{C}=\mathrm{C} 0 \times \mathrm{FCw} \times \mathrm{FCsp} \times \mathrm{FCsf}(\mathrm{smp} / \mathrm{jam})
$$

Di mana :

$\mathrm{C}=$ kapasitas

$\mathrm{CO}=$ kapasitas dasar (smp/jam) 


$$
\begin{aligned}
& \text { FCW = factor penyesuaian akibat lebar lajur } \\
& \text { lalu }- \text { lintas } \\
& \begin{aligned}
\text { FCSP = } & \text { factor penyesuaian akibat pemisah } \\
& \text { arah }
\end{aligned} \\
& \text { FCSF = factor penyesuaian akibat hambatan } \\
& \text { samping }
\end{aligned}
$$

f. Lebar Lajur

Lebar lajur dipengaruhi oleh ukuran dan kecepatan kendaraan, klasifikasi lebar lajur menurut kelas jalan dijelaskan di tabel berikut:

Tabel 2. Lebar Lajur

\begin{tabular}{|c|c|c|c|c|c|}
\hline Kelas & $\begin{array}{c}1 \\
\text { dan } \\
1^{*}\end{array}$ & 2 & $\begin{array}{c}3 \\
\text { dan } \\
3^{*}\end{array}$ & $\begin{array}{c}4 \\
\text { dan } \\
4^{*}\end{array}$ & $\begin{array}{c}5 \text { dan } \\
5^{*}\end{array}$ \\
\hline $\begin{array}{c}\text { Lebar } \\
\text { Lajur }\end{array}$ & 3,50 & 3,25 & 3,00 & 2,75 & $\begin{array}{c}4,50(1 \\
\text { lajur })\end{array}$ \\
\hline
\end{tabular}

Sumber : "Spesifikasi Standar Untuk Rencana Geometrik Jalan Antar Kota (rancangan akhir), Bina Marga 1990"

\section{Perencanaan tebal perkerasan lentur}

a. Perkerasan Lentur (Flexible Pavement)

Perkerasan disebut sebagai lapisan permukaan, dimana secara langsung berhubungan dengan kendaraan sehingga rawan terhadap kerusakan akibat aus. Material pengikat yang digunakan adalah material aspal dengan mempunyai fungsi yaitu untuk menyalurkan beban lalu lintas menuju tanah dasar. Secara umum lapisan perkerasan lentur terdiri dari 3 (tiga) lapisan yaitu lapis tanah dasar, lapisan untuk pondasi bawah, lapisan untuk pondasi atas, dan lapisan permukaan.

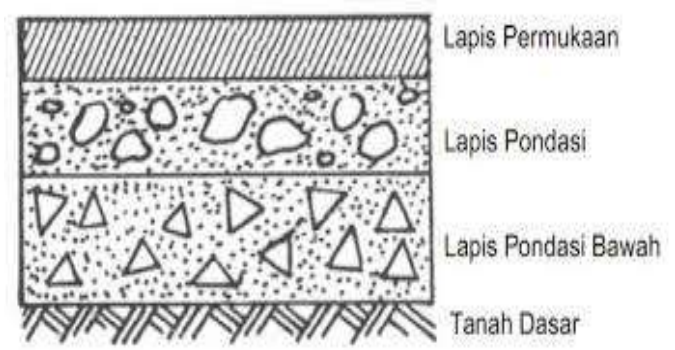

Gambar 1. Struktur Perkerasan Lentur (Sumber: Bina Marga Pt T-01-2002-B)

b. Perencanaan Tebal Lapis Perkerasan
Lentur

Perencanaan tebal perkerasan yang dilakukan dalam Perencanaan jalan Matingan - Ngabul / jalan Sultan Hadlirin Kabupaten Jepara ini menggunakan jenis perkerasan lentur (Flexible Pavement). Perkerasan lentur adalah jenis konstruksi perkerasan bidang permukaan jalan dengan bahan aspal sebagai lapis permukaan, serta bahan berbutir atau agregat di bawahnya. Parameter yang digunakan dalam perencanaan tebal perkerasan lentur untuk jalan jalan Matingan Ngabul / jalan Sultan Hadlirin Kabupaten Jepara antara lain (Direktorat Jenderal Bina Marga 1987):

- Lalu Lintas

- Angka Ekuivalen (E) Beban Sumbu Kendaraan

- Faktor Regional (FR)

c. Daya Dukung Tanah Dasar (DDT)

Daya Dukung Tanah Dasar (DDT) ditetapkan berdasarkan grafik korelasi. Yang dimaksud dengan data CBR disini adalah harga CBR lapangan atau CBR labratorium. Bila nilai CBR rencana diketahui.

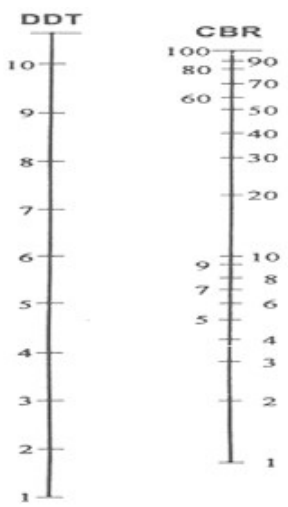

Gambar 2. Grafik Kolerasi DDT dan CBR

(Sumber: Bina Marga Pt T-01-2002-B)

d. Indek Permukaan (IP)

Indek permukaan adalah nilai dari suatu kehalusan dan kekuatan pada permukaan jalan yang berhubungan dengan tingkat pelayanan lalu lintas. Dari nilai indek permukaan awal (IPo) dapat di hasilkan dari jenis lapis permukaan dan indek permukaan akhir (IPt) yang dihasilkan dari nilai LER.

e. Indek Tebal Perkerasan (ITP)

Untuk mengetahui hasil nilai ITP diperoleh dengan nomogram yang angka-angkanya telah diketahui sebelumnya, berupa LER selama umur rencana, DDT, dan FR

f. Koefisien Kekuatan Relatif

Setelah nilai ITP diketahui dari grafik nomogram, maka nilai koefisien kekuatan relative (a) dan tebal minimum lapis 
perkerasan (D) dapat dihitung sesuai dengan Bina Marga Pt T-01-2002-B

g. Tebal Minimum Lapis Perkerasan

Dapat diperoleh dari tabel batas minimum lapis permukaan dan lapis pondasi berdasarkan SKBI-2.3.26.1987 (Bina Marga, 1987). Nilai ITP dapat dihitung dengan rumus sebagai berikut:

$$
\text { ITP = a1.D1+a2.D2+a3.D3 }
$$

Di mana :

$\mathrm{a} 1, \mathrm{a} 2, \mathrm{a} 3=$ koefisien kekuatan relatif bahan untuk masing-masing lapisan perkerasan

D1,D2,D3 = tebal masing-masing lapis perkerasan

\section{Geometrik jalan raya}

Perencanaan geometrik jalan adalah perencanaan ruas jalan secara lengkap, meliputi beberapa elemen yang disesuaikan dengan kelengkapan data dari hasil survey lapangan dan telah dianalisis, yang mengacu pada ketentuan yang berlaku.

Ada 2 (dua) bagian penting yang harus diperhatikan dalam merencanakan geometrik jalan yaitu desain alinyemen horizontal meliputi penggunaan jenis tikungan dan alinyemen vertikal yang berkaitan dengan tanjakan maupun turunan pada sebuah jalan.

Elemen dalam perencanaan geometrik jalan, yaitu :

a. Alinyemen Horizontal (Situasi/Plan)

b. Alinyemen Vertikal (Potongan Memanjang / Profil)

c. Potongan Melintang (Cross Section)

d. Penggambaran

\section{METODE PENELITIAN}

Lokasi perencanaan berada di jalan Matingan - Ngabul / jalan Sultan Hadlirin Kabupaten Jepara. Tahap persiapan terdiri dari studi literatur, mencari Informasi terkait dan mengumpulkan data. Dalam proses pengumpulan data diperlukan data-data primer (data lalu lintas dan kondisi lapangan) dan sekunder (data lalu-lintas dan data tanah). Berikut diagram alur penelitiannya.

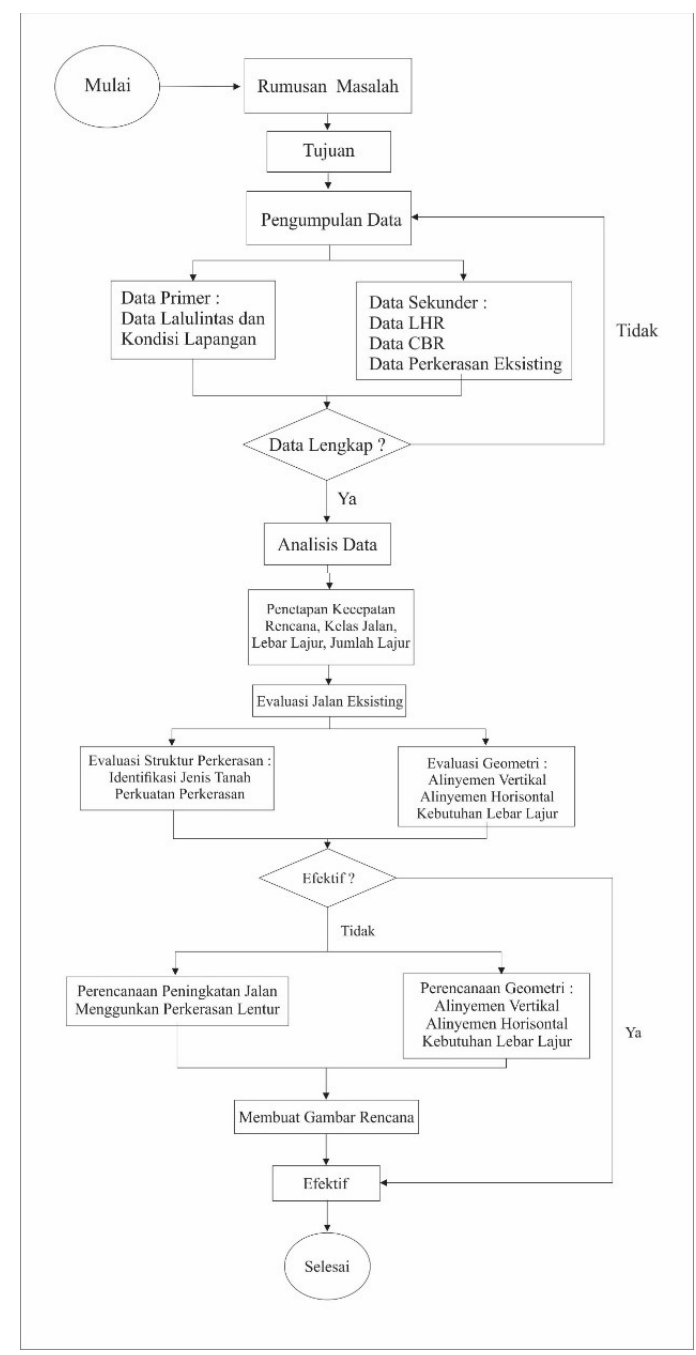

Gambar 3. Diagram alur penelitian

\section{HASIL DAN PEMBAHASAN}

1. Data Perencanaan Jalan

$\begin{array}{lll}\text { Klasifikasi Jalan } & : \text { Lokal } \\ \text { Jenis Perkerasan } & : \text { Aspal } \\ \text { Lebar Perkerasan } & : \text { meter } \\ \text { Panjang Jalan } & : \text { 5.000 m } \\ \text { Umur Rencana } & : \text { 20 tahun }\end{array}$

a. Data Lalu Lintas

Survei pencacahan lalu lintas manual di ambil pada tanggal 7 januari 2020. Hasilnya bisa dilihat di tabel berikut ini : 
Tabel 3. Survei Pencacahan Lalu Lintas Manual

\begin{tabular}{|c|c|c|c|c|c|c|}
\hline \multirow[b]{2}{*}{$\begin{array}{l}\text { Interval } \\
\text { Waktu }\end{array}$} & \multicolumn{3}{|c|}{$\begin{array}{l}\text { Kend. } \\
\text { Ringan }\end{array}$} & \multirow{2}{*}{ 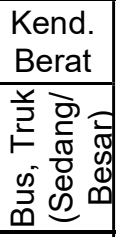 } & \multirow[b]{2}{*}{$\begin{array}{l}\text { Spd } \\
\text { Motor }\end{array}$} & \multirow{2}{*}{ 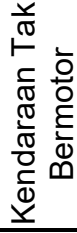 } \\
\hline & $\begin{array}{l}\overline{\overline{0}} \\
\overline{2}\end{array}$ & 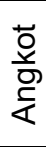 & $\begin{array}{l}\frac{}{2} \\
\frac{u}{0} \\
\frac{0}{2}\end{array}$ & & & \\
\hline $\begin{array}{l}06.00- \\
07.00\end{array}$ & 18 & 7 & 25 & 15 & 1281 & 0 \\
\hline $\begin{array}{l}07.00- \\
08.00\end{array}$ & 27 & 6 & 35 & 16 & 605 & 1 \\
\hline $\begin{array}{l}11.00- \\
12.00\end{array}$ & 21 & 5 & 18 & 7 & 428 & 2 \\
\hline $\begin{array}{l}12.00- \\
13.00\end{array}$ & 15 & 1 & 14 & 5 & 417 & 0 \\
\hline $\begin{array}{c}15.00- \\
16.00 \\
\end{array}$ & 27 & 0 & 0 & 22 & 920 & 0 \\
\hline $\begin{array}{l}16.00- \\
17.00\end{array}$ & 22 & 0 & 0 & 20 & 561 & 0 \\
\hline
\end{tabular}

Sumber: survei 2020

b. Pertumbuhan Lalu Lintas

Tabel 4. Data Lalu Lintas Pertahun

\begin{tabular}{|c|c|}
\hline Tahun & Lalu Lintas ( Kendaraan / Hari) \\
\hline 2017 & 4102 \\
\hline 2018 & 4369 \\
\hline 2019 & 4373 \\
\hline 2020 & 4440 \\
\hline
\end{tabular}

Sumber: Dinas Perhubungan Jepara

Pertumbuhan lalu lintas 2017-2018

$$
i=\frac{4102-4369}{4369} \times 100=6.1 \%
$$

Pertumbuhan lalu lintas 2018-2019

$$
\mathrm{i}=\frac{4369-4373}{4373} \times 100=0.1 \%
$$

Pertumbuhan lalu lintas 2019-2020

$$
i=\frac{4373-4440}{4440} \times 100=1.5 \%
$$

Maka pertumbuhan lalu lintas rata-rata adalah

$$
\frac{6.1 \%+0.1 \%+1.5 \%}{3}=2.6 \%
$$

\begin{tabular}{|c|c|c|}
\hline TITIK & STA & CBR (\%) \\
\hline 1 & sta 0.00 & 1.65 \\
\hline 2 & sta 0.250 & 1.64 \\
\hline 3 & sta 0.500 & 1.72 \\
\hline 4 & sta 0.750 & 1.16 \\
\hline 5 & sta 1.000 & 1.67 \\
\hline 6 & sta 1.250 & 1.06 \\
\hline 7 & sta 1.500 & 1.16 \\
\hline 8 & sta 1.750 & 1.16 \\
\hline 9 & sta 2.000 & 1.63 \\
\hline 10 & sta 2.250 & 1.15 \\
\hline 11 & sta 2.500 & 1.01 \\
\hline 12 & sta 2.750 & 1.00 \\
\hline 13 & sta 3.000 & 1.06 \\
\hline 14 & sta 3.250 & 1.16 \\
\hline 15 & sta 3.500 & 1.70 \\
\hline 16 & sta 3.750 & 1.37 \\
\hline 17 & sta 4.000 & 1.28 \\
\hline 18 & sta 4.250 & 1.26 \\
\hline 19 & sta 4.500 & 1.73 \\
\hline 20 & sta 4.750 & 1.37 \\
\hline 21 & sta 5.000 & 1.72 \\
\hline \multicolumn{2}{|c|}{ TOTAL } & 28.65 \\
\hline
\end{tabular}

c. Data CBR (California Bearing Ratio)

Tabel 5. Data CBR (California Bearing Ratio)

Sumber analisis 2020

Perhitungan Nilai CBR Dengan Metode

Analisis :

CBR rata-rata $=$ Jumlah total CBR / Jumlah titik

$=28.65 / 21$

$=1.4 \%$

CBR maks $\quad=1.73 \%$

CBR min $\quad=1 \%$

CBR Segmen $=$ CBR rata-rata $-((\mathrm{CBR}$

maks - CBR $\min ) / R)$

$=1.4-((1.73-1) / 3.18)$

$=1.13 \%$ 
d. Menentukan Angka Ekivalen

Tabel 6. Data Angka Ekivalen

\begin{tabular}{|c|c|c|c|}
\hline \multicolumn{2}{|c|}{ Beban Sumbu } & \multicolumn{2}{c|}{ Angka Ekuivalen } \\
\hline $\mathrm{Kg}$ & Lb & $\begin{array}{c}\text { Sumbu } \\
\text { Tunggal }\end{array}$ & $\begin{array}{c}\text { Sumbu } \\
\text { Ganda }\end{array}$ \\
\hline 1000 & 2205 & 0,002 & - \\
2000 & 4409 & 0,0036 & 0,0003 \\
3000 & 6614 & 0,0183 & 0,0016 \\
4000 & 8818 & 0,0577 & 0,0050 \\
5000 & 11023 & 0,1410 & 0,0121 \\
6000 & 13228 & 0,2923 & 0,0251 \\
7000 & 15432 & 0,5415 & 0,0466 \\
8000 & 17637 & 0,9238 & 0,0795 \\
8160 & 18000 & 1,000 & 0,086 \\
9000 & 19841 & 1,4798 & 0,1273 \\
\hline 10000 & 22046 & 2,2555 & 0,1940 \\
11000 & 24251 & 3,3022 & 0,2840 \\
12000 & 26455 & 4,6770 & 0,4022 \\
13000 & 28660 & 6,4419 & 0,5540 \\
14000 & 30864 & 8,6647 & 0,7452 \\
15000 & 33069 & 11,4184 & 0,9820 \\
16000 & 35276 & 14,7815 & 1,2712 \\
\hline
\end{tabular}

Sumber : Metode Analisa Komponen, DPU (1987)

Bersumber tabel diatas Angka Ekivalen dari masing-masing sumbu adalah sebagai berikut:

$\begin{array}{ll}\text { Sepeda motor }(1) & =0.0002 \\ \text { Mobil }(1+1) & =0.0004 \\ \text { Pick Up }(2+3) & =0.0213\end{array}$

Truk sedang/besar $(5+6+7)=0.71173$

e. Menentukan Angka LEP (Lintas Ekivalen Permulaan)

Tabel 7. Data Angka Lintas Ekivalen Permulaan

\begin{tabular}{|c|c|c|c|c|}
\hline $\begin{array}{c}\text { Jenis } \\
\text { Kendara } \\
\text { an }\end{array}$ & $\begin{array}{c}\text { Jumlah } \\
\text { Kendaraan } \\
\text { /Hari } \\
\text { Tahun } \\
2020\end{array}$ & CJ & EJ & LEP \\
\hline $\begin{array}{c}\text { Sepeda } \\
\text { motor \& } \\
\text { roda 3 }\end{array}$ & 4212 & 0.5 & 0.002 & 4.21 \\
\hline Mobil & 94 & 0.5 & 0.004 & 0.19 \\
\hline Pick up & 60 & 0.5 & 0.021 & 0.64 \\
\hline $\begin{array}{c}\text { Truk } \\
\text { sedang / } \\
\text { Besar }\end{array}$ & 74 & 0.5 & 0.712 & 26.33 \\
\hline \multicolumn{4}{|c|}{ TOTAL } & \\
\hline
\end{tabular}

Sumber analisis 2020 f. Menentukan LEA (Lintas Ekivalen Akhir)

$$
\text { LEA }=\text { LHR } \times \mathrm{Cj} \times \mathrm{Ej}
$$

Keterangan :

LHR : Lalu lintas harian rata-rata

Cj : Koefisien distribusi arah

Ej :Masing-masing jenis kendaraan

Contoh Perhitungan :

Sepeda motor $=4789 \times 0.5 \times 0.002$

$$
=4.79
$$

\section{g. Menentukan LET (Lintas Ekivalen Tengah)}

Tabel 8. Lintas Ekivalen Tengah 5 Tahun

(2025)

\begin{tabular}{|c|c|c|}
\hline LEP 2020 & LEA 2025 & LET 5 tahun \\
\hline 31.37 & 35.67 & 33.52 \\
\hline
\end{tabular}

Sumber analisis 2020

Perhitungan Lintas Ekivalen Tengah 5 tahun (2025)

LET 5 tahun $=0.5 \times$ LEP $2020 \times$ LEA 2025

LET 5 tahun $=0.5 \times 31.37 \times 35.67$

$$
=33.52
$$

h. Menentukan LER (Lintas Ekivalen Rencana)

$$
\text { LER }=\text { LET } \times \frac{\text { UR }}{10}
$$

Tabel 9. Lintas Ekivalen Rencana

\begin{tabular}{|c|c|c|c|}
\hline Tahun & LET & UR & LER \\
\hline 5 & 33.52 & 5 & 16.76 \\
\hline 10 & 38.11 & 10 & 38.11 \\
\hline 15 & 43.33 & 15 & 65.00 \\
\hline 20 & 49.27 & 20 & 98.53 \\
\hline
\end{tabular}

Sumber analisis 2020

i. Menentukan Indeks Tebal Perkerasan Perhitungan DDT dengan cara logaritma :

$$
\begin{aligned}
\text { DDT } & =1.6649+4.3592 \log (\mathrm{CBR}) \\
& =1.6649+4.3592 \log (1.13) \\
& =1.90 \mathrm{~kg} / \mathrm{cm} 2
\end{aligned}
$$

Perhitungan nilai ITP

$$
\begin{aligned}
& =(\mathrm{a} 1 \times \mathrm{D} 1)+(\mathrm{a} 2 \times \mathrm{D} 2)+(\mathrm{a} 3 \times \mathrm{D} 3) \\
& =4+2.8+3.302 \\
& =10.102
\end{aligned}
$$

Jika nilai ITP dari grafik nomogram sebesar 10.1 dan jumlah perhitungan nilai ITP 10.102, maka dapat di nyatakan perencanaan tebal perkerasan jalan sudah aman. 


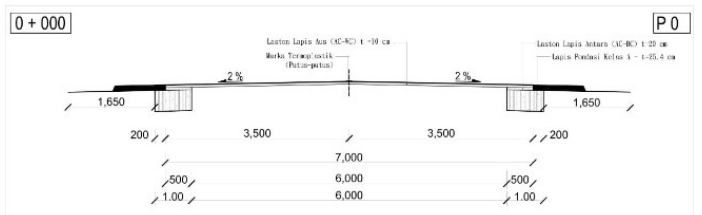

Gambar 4. Gambar Potongan Melintang Sta $0+000$

j. Perhitungan Lebar Jalan

Tabel 10. Penentuan Lebar Jalan dan Bahu Jalan

\begin{tabular}{|c|c|c|c|c|}
\hline \multirow[b]{3}{*}{$\begin{array}{c}\text { VLHR } \\
\text { (smp/hari) }\end{array}$} & \multicolumn{4}{|c|}{ ARTERI } \\
\hline & \multicolumn{2}{|c|}{ Ideal } & \multicolumn{2}{|c|}{ Minimum } \\
\hline & $\begin{array}{c}\text { Lebar } \\
\text { Jalur } \\
\text { (m) }\end{array}$ & $\begin{array}{c}\text { Lebar } \\
\text { Bahu } \\
\text { (m) }\end{array}$ & $\begin{array}{c}\text { Lebar } \\
\text { Jalur } \\
\text { (m) }\end{array}$ & $\begin{array}{c}\text { Lebar } \\
\text { Bahu } \\
\text { (m) }\end{array}$ \\
\hline$<3000$ & 6.0 & 1.5 & 4.5 & 1.0 \\
\hline $\begin{array}{c}3000- \\
10.000\end{array}$ & 7.0 & 2.0 & 6.0 & 1.5 \\
\hline $\begin{array}{l}10.000- \\
25.000\end{array}$ & 7.0 & 2.0 & 7.0 & 2.0 \\
\hline$>25.000$ & $\begin{array}{l}2 \mathrm{n} x \\
\left.3.5^{*}\right)\end{array}$ & 2.5 & $\begin{array}{c}2 \times \\
\left.7.0^{*}\right)\end{array}$ & 2.0 \\
\hline \multirow{3}{*}{$\begin{array}{c}\text { VLHR } \\
\text { (smp/hari) }\end{array}$} & \multicolumn{4}{|c|}{ KOLEKTOR } \\
\hline & \multicolumn{2}{|c|}{ Ideal } & \multicolumn{2}{|c|}{ Minimum } \\
\hline & $\begin{array}{c}\text { Lebar } \\
\text { Jalur } \\
\text { (m) }\end{array}$ & $\begin{array}{c}\text { Lebar } \\
\text { Bahu } \\
\text { (m) }\end{array}$ & $\begin{array}{c}\text { Lebar } \\
\text { Jalur } \\
(\mathrm{m})\end{array}$ & $\begin{array}{c}\text { Lebar } \\
\text { Bahu } \\
(\mathrm{m})\end{array}$ \\
\hline$<3000$ & 6.0 & 1.5 & 4.5 & 1.0 \\
\hline $\begin{array}{c}3000- \\
10.000\end{array}$ & 7.0 & 1.5 & 6.0 & 1,5 \\
\hline $\begin{array}{l}10.000- \\
25.000\end{array}$ & 7.0 & 2.0 & $* *)$ & $* *)$ \\
\hline$>25.000$ & $\begin{array}{l}2 \mathrm{nx} \\
\left.3.5^{*}\right)\end{array}$ & 2.0 & $* *)$ & $* *)$ \\
\hline \multirow[b]{3}{*}{$\begin{array}{c}\text { VLHR } \\
\text { (smp/hari) }\end{array}$} & \multicolumn{4}{|c|}{ LOKAL } \\
\hline & \multicolumn{2}{|c|}{ Ideal } & \multicolumn{2}{|c|}{ Minimum } \\
\hline & $\begin{array}{c}\text { Lebar } \\
\text { Jalur } \\
\text { (m) }\end{array}$ & $\begin{array}{c}\text { Lebar } \\
\text { Bahu } \\
\text { (m) }\end{array}$ & $\begin{array}{c}\text { Lebar } \\
\text { Jalur } \\
(\mathrm{m})\end{array}$ & $\begin{array}{c}\text { Lebar } \\
\text { Bahu } \\
\text { (m) }\end{array}$ \\
\hline$<3000$ & 6.0 & 1.0 & 4.5 & 1.0 \\
\hline $\begin{array}{c}3000- \\
10.000\end{array}$ & 7.0 & 1.5 & 6.0 & 1.0 \\
\hline $\begin{array}{l}10.000- \\
25.000\end{array}$ & - & - & - & - \\
\hline$>25.000$ & - & - & - & - \\
\hline
\end{tabular}

Keterangan:

${ }^{* *}$ )Mengacu pada persyaratan

*) 2 jalur terbagi, masing masing $n \times 3.5 m$, dimana $n$ jumlah lajur per jalur

- Tidak ditentukan

Sumber : Tata Cara Perencanaan Geometrik Jalan Raya Antar Kota, 1997

\section{SIMPULAN}

Perencanaan peningkatan ruas jalan Mantingan - Ngabul / jalan Sultan Hadlirin Kabupaten Jepara dapat disimpulkan sebagai berikut :

a. Tebal perkerasan lentur untuk umur rencana 20 tahun adalah sebesar $10 \mathrm{~cm}$ menggunakan AC-WC Laston MS744

b. Analisis perencanaan peningkatan ruas jalan Mantingan - Ngabul / jalan Sultan Hadlirin Kabupaten Jepara adalah sebagai berikut :

Pelebaran jalan ideal untuk jalan ini adalah minimal $6 \mathrm{~m}$, tetapi saat ini jalan sudah di lebarkan sebesar $7 \mathrm{~m}$. Jadi perencanaan sebelumnya sudah sesuai.

c. Sesuai dengan analisis perhitungan Indeks Tebal Perkerasan (ITP) diatas, maka ditentukan tebal perkerasan jalan untuk umur rencana 20 tahun adalah
- Laston MS 744
$=10 \mathrm{~cm}$
-Batu Pecah Kelas A (CBR100\%) $=20 \mathrm{~cm}$
-Sirtu Kelas A (CBR70\%) $\quad=25.4 \mathrm{~cm}$

d. Hasil analisis geometrik jalan raya di dapat 5 tikungan, dan ke 5 tikungan tersebut masuk kedalam jenis tikungan S-S dan membentuk lengkung cekung di alinyemen vertikalnya, dengan rincian sebagai berikut:

- Tikungan 1 : membutuhkan kebebasan samping $2.75 \mathrm{~m}$ dan tidak diperlukan pelebaran tikungan karena kebutuhan lebar tikungan sebesar $6.49 \mathrm{~m}$ sedangkan lebar tikungan saat ini sebesar $7 \mathrm{~m}$.

- Tikungan 2 : membutuhkan kebebasan samping $3.17 \mathrm{~m}$ dan tidak diperlukan pelebaran tikungan karena kebutuhan lebar tikungan sebesar $6.51 \mathrm{~m}$ sedangkan lebar tikungan saat ini sebesar $7 \mathrm{~m}$.

- Tikungan 3 : membutuhkan kebebasan samping $13.725 \mathrm{~m}$ dan diperlukan pelebaran tikungan sebesar $1 \mathrm{~m}$ dari lebar asli sebesar $7 \mathrm{~m}$.

- Tikungan 4 : membutuhkan kebebasan samping $2.80 \mathrm{~m}$ dan tidak diperlukan pelebaran tikungan karena kebutuhan lebar tikungan sebesar $6.68 \mathrm{~m}$ sedangkan lebar tikungan saat ini sebesar $7 \mathrm{~m}$.

- Tikungan 5 : membutuhkan kebebasan samping $3.11 \mathrm{~m}$ dan tidak diperlukan pelebaran tikungan karena kebutuhan 
lebar tikungan sebesar $6.52 \mathrm{~m}$ sedangkan lebar tikungan saat ini sebesar $7 \mathrm{~m}$.

e. Sesuai analisis, kapasitas ruas jalan Mantingan - Ngabul / jalan Sultan Hadlirin Kabupaten Jepara di dapat angka pertumbuhan lalu lintas rata-rata sebesar $2.6 \%$ dan jumlah LHR per tahunnya sebagai berikut :

Tahun $2020: 4440$ jumlah kendaraan/hari Tahun 2025 : 5048 jumlah kendaraan/hari Tahun 2030 : 5739 jumlah kendaraan/hari Tahun 2035 : 6525 jumlah kendaraan/hari Tahun 2040 : 7419 jumlah kendaraan/hari

\section{DAFTAR PUSTAKA}

Aldilase, Bima Prahar, Sahil Riskie Tamara, Moga Narayudha, and Wahyudi Kushardjoko. 2014. "Analisa Dan Perencanaan Peningkatan Jalan Alternatif Manyaran - Mijen." Jurusan Teknik Sipil, Fakultas Teknik, Universitas Diponegoro Semarang.

Badrujaman, Aceng. 2016. "Perencanaan Geometrik Jalan Dan Anggaran Biaya Ruas Jalan Cempaka - Wanaraja Kecamatan Garut Kota." Sekolah Tinggi Teknologi Garut.

Bethary, Rindu Twidi, M. Fakhruriza Pradana, and M. Bara Indinar. 2016. "Perencanaan Geometrik Jalan Alternatif Palima - Curug ( Studi Kasus: Kota Serang )." Jurusan Teknik Sipil, Fakultas Teknik, Universitas Sultan Ageng Tirtayasa Banten.

Departemen Permukiman dan Prasarana Wilayah. 2002. "Pedoman Perencanaan Tebal Perkerasan Lentur." Jakarta: Departemen Pekerjan Umum.

Direktorat Jenderal Bina Marga. 1987. "Petunjuk Perencanaan Tebal Perkerasan Lentur Jalan Raya Dengan Metode Analisa Komponen." Jakarta: Departemen Pekerjan Umum..

Direktorat Jenderal Bina Marga. 1997a. "Manual Kapasitas Jalan Indonesia." Jakarta: Departemen Pekerjan Umum.

Direktorat Jenderal Bina Marga. 1997b. "Tata Cara Perencanaan Geometrik Jalan Antar Kota." Jakarta: Departemen Pekerjan Umum.

Direktorat Jenderal Bina Marga. 2018. "Spesifikasi Umum Untuk Pekerjaan
Konstruksi Jalan Dan Jembatan 2018." Jakarta: Departemen Pekerjan Umum.

Kurniawan, Febri and Sudarno. 2018. "Analisi Geometrik Pada Tikungan Ruas Jalan Raya Magelang-Kopeng Dan Jalan Raya Soekarno - Hatta." Jurusan Teknik Sipil, Fakultas Teknik, Universitas Tidar Magelang.

Mamari, Roy Laban P. 2017. "Studi Perencanaan Perkerasan Lentur Jalan Raya Dengan Standar Bina Marga Pada Ruas Jalan Sentani-Warumbain KM 41+000-KM 61+000 (20 KM)." Jurusan Teknik Sipil, Fakultas Teknik Sipil Dan Perencanaan, Institut Teknologi Nasional Malang.

Marpaung, Tumanda Iskandi, Katharina Indah Sushmita, Eko Yuli Priyono, and Bambang Pudjianyo. 2017. "Perencanaan Jalan Alternatif Kampus UNDIP Tembalang - Spata Marga." Jurusan Teknik Sipil, Fakultas Teknik, Universitas Diponegoro.

Ningrum, Aprilia Fitri Nuryati, Karib Wicaksono, Moga Narayudha, and Siti Hardiyati. 2016. "Perencanaan Peningkatan Jalan Tembus Jl. Ambarawa- Jl. Soekarno Hatta,Bawen, Semarang." Jurusan Teknik Sipil, Fakultas Teknik, Universitas Negeri Diponegoro Semarang.

Pratama, Yoga and Suharmono. 2017. "Peningkatan Jalan Dengan Menggunakan Perkerasan Lentur Ruas Jalan Beru-Cinandang (STA 0+000 3+000) Kecamatan Dawar Blandong Kabupaten Mojokerto." Jurusan Diploma Teknik Sipil, Fakultas Teknik Sipil Dan Perencanaan, Institut Teknologi Sepuluh Nopember Surabaya.

Saputro, Yayan Adi. 2017. "Analisis Alinyemen Horizontal, Alinyemen Vertikal, Dan Tebal Perkerasan Lentur Jalan Raya Batealit - Bangsri KM.3 Sampai KM.5 Kabupaten Jepara." Jurusan Teknik Sipil, Fakultas Sains Dan Teknologi, Universitas Islam Nahdlatul Ulama Jepara.

Satriawan, Dicky, Taufik, and Eva Rita. 2013. "Perencanaan Geometrik Jalan Raya Dan Perkerasan Lentur Di Ruas Jalan Lubuk Selasih - Surian Kabupaten Solok 
(STA $23+800$ - STA $26+600$ )." Jurusan Teknik Sipil. Fakultas Teknik Sipil Dan Perencanaan, Universitas Bung Hatta Padang.

Standar Nasional Indonesia. 2004. "Geometri Jalan Perkotaan." Jakarta : Badan Standarisasi Nasional.

Standar Nasional Indonesia. 2012. "Metode Uji CBR Laboratorium." Jakarta : Badan Standarisasi Nasional. 